\title{
Pancreatic Cancer Screening
}

\author{
Eun Ji Shin, MD and Marcia Irene Canto, MD, MHS ${ }^{*}$ \\ Department of Internal Medicine, Division of Gastroenterology and Hepatology, Johns Hopkins \\ University School of Medicine, 1830 East Monument Street, Baltimore, MD 21205, USA
}

\section{Keywords}

Pancreatic cancer; Genetic predisposition; Tumor markers; Screening

\section{PANCREATIC CANCER: WHY CONSIDER SCREENING?}

Pancreatic cancer remains one of the most deadly diseases, despite significant advances in medicine over the past decade. Pancreatic adenocarcinoma is the fourth leading cause of cancer deaths in the United States for both males and females, with an estimated 44,030 new cases and 37,660 deaths in $2011 .{ }^{1}$ In contrast to the death rates for other leading causes of cancer death (lung, colorectal, breast, and prostate), which have declined since 2003, the death rate from pancreatic adenocarcinoma has increased during the same time period. ${ }^{1}$ Unfortunately, the majority of symptomatic patients are incurable. The prognosis for patients with pancreatic adenocarcinoma remains poor: a 5-year relative survival rate of $6 \%$ for all stages combined, most likely because of the late stage of disease at the time of diagnosis. Hence, there has been a strong interest in detecting precursor lesions or small asymptomatic cancers that are potentially curable. A widespread screening program does not seem feasible or cost effective given the relatively low incidence of the disease, accounting for 3\% of all new cancer cases in the United States, and the lack of accurate, inexpensive, and noninvasive diagnostic tests for early lesions. However, screening may be desirable in the selected population at increased risk for developing pancreatic adenocarcinoma.

\section{GENETIC PREDISPOSITION TO PANCREATIC CANCER}

Although the great majority of pancreatic adenocarcinoma cases are thought to be sporadic in nature, up to $10 \%$ of cases can be attributed to genetic factors. ${ }^{2-4}$ In fact, familial clustering of pancreatic cancer was noted as early as 1967, when Lynch and colleagues reported on an adenocarcinoma-prone family. ${ }^{5}$ Familial pancreatic cancer (FPC) is characterized by two or more first-degree relatives (FDRs) with pancreatic adenocarcinoma in the absence of known cancer syndromes or other diseases with known genetic defect. Individuals from a family with a pair of affected FDRs have a higher risk (6.4-fold to 32fold) of developing pancreatic cancer. ${ }^{6-9}$ Thus far, the key causative gene or genes leading to the inherited predisposition in familial pancreatic cancer have not yet been fully elucidated. Complex segregation analysis suggests that this predisposition may be due to a novel rare major gene with an autosomal dominant inheritance with reduced penetrance. ${ }^{10-13}$ 
Initial linkage analysis suggested that the mutation of the palladin gene may be involved in the development of pancreatic cancer in a specific kindred. ${ }^{14}$ However, the initial excitement has been tempered by the failure of population-based studies in Canada and Europe to demonstrate that mutations in the palladin gene are more common in those with FPC as compared to controls. ${ }^{15-18}$ Further, a study evaluating the pattern of palladin protein expression in 177 cases of pancreatic adenocarcinoma determined that although the palladin protein is overexpressed in the stroma, it is not overexpressed in the neoplastic cells in pancreatic cancer. ${ }^{19}$

To date, germline breast cancer 2 (BRCA2) mutation appears to be the most common genetic abnormality in patients from FPC kindreds who develop pancreatic adenocarcinoma, but still have been reported in only $6 \%$ to $19 \%$ of all FPC kindreds. ${ }^{20-22}$ Mutations in the $B R C A 2$ gene can be present even in the absence of breast or ovarian cancer, and in apparently sporadic pancreatic cancer. Recent studies have identified another associated inheritable gene mutation, partner and localizer for breast cancer 2 gene (PALB2), as a pancreatic adenocarcinoma susceptibility gene, which may be causative for $3 \%$ to $4 \%$ of FPC. ${ }^{7,9}$ The PALB2 protein directly binds to the breast cancer 1 gene (BRCA1) and acts as a bridge between $B R C A 1$ and $B R C A 2$ to form a complex involved in double-strand break repair. ${ }^{23}$ The $P A L B 2$ gene is present in $1 \%$ to $2 \%$ of patients with familial breast cancer. Subsequent testing of patients with a personal history of breast and pancreatic cancer ${ }^{24}$ and also of non-BRCA1 and non-BRCA2 breast cancer women with a personal or family history of pancreatic cancer ${ }^{25}$ has shown the $P A L B 2$ mutation to be a very uncommon mutation. The clinical utility of routine testing of FPC patients for $P A L B 2$ has not been proven.

\section{INHERITED CANCER SYNDROMES}

\section{Hereditary Pancreatitis}

Hereditary pancreatitis is a rare inherited disorder characterized by recurrent attacks of acute pancreatitis in childhood or early adolescence, followed by the development of chronic pancreatitis in late adolescence or early adulthood. ${ }^{26}$ It is transmitted as an autosomal dominant disorder with incomplete penetrance. ${ }^{27}$ Most are due to germ-line gain-of-function mutations in a cationic trypsinogen gene (PRSSI) on chromosome $7 \mathrm{q} 35 .{ }^{28-30}$ Mutations in PRSS1 cause premature trypsin activation and ineffective autodegradation of active trypsin mutants, leading to autodigestion and acute pancreatitis. ${ }^{31}$ Hereditary pancreatitis is associated with one of the highest estimated lifetime risks for developing pancreatic cancer among the inherited pancreatic cancer syndromes, with a lifetime risk approaching $40 \%{ }^{32,33}$ Particularly in those individuals with a paternal inheritance pattern, the cumulative risk for developing pancreatic cancer is approximately $75 \% .32$ Tobacco smoking increases the risk even further in this population, by approximately twofold, and decreases the age at onset of pancreatic cancer by approximately 20 years. ${ }^{27,34}$

\section{Peutz-Jeghers Syndrome}

Peutz-Jeghers syndrome is an autosomal dominantly inherited polyposis syndrome with high penetrance. The reported frequency of Peutz-Jeghers syndrome is 1 in 8300 to 280,000 individuals. ${ }^{35}$ It is characterized by hamartomatous polyps of the gastrointestinal (GI) tract and mucocutaneous pigmentation. It is caused by an inherited germline mutation of the $S T K 11 / L K B 1$ tumor-suppressor gene. ${ }^{36}$ Patients with Peutz-Jeghers syndrome have a significantly increased lifetime risk for multiple GI cancers, including esophageal (0.5\%), stomach (29\%), small intestinal (13\%), and colon (39\%). ${ }^{37}$ These patients are also at increased risk for non-GI cancers, including breast (54\%), lung (15\%), ovarian (21\%), cervical (10\%), uterine (9\%), and testicular (9\%). The cumulative lifetime risk for developing pancreatic cancer is $36 \%$, with a relative risk (RR) of $132 .{ }^{37}$ 


\section{Familial Atypical Multiple Mole Melanoma}

Familial atypical multiple mole melanoma is an autosomally dominant disease with variable penetrance. It is characterized by familial occurrence of multiple benign melanocytic nevi, dysplastic nevi, and melanoma. ${ }^{38}$ It is associated with germline mutations in the $\mathrm{p} 16 /$ CDKN2A gene. ${ }^{39,40}$ This syndrome is associated with an increased risk of sarcomas and endometrial, breast, and lung cancers. ${ }^{41,42}$ There is an approximately 13 -fold to 22 -fold increased risk of pancreatic cancer in these patients compared to the general population. ${ }^{42,43}$

\section{Lynch Syndrome}

Patients with hereditary nonpolyposis colorectal cancer syndrome, also known as Lynch syndrome, have mutations in the mismatch repair genes (MLH1, MSH2, MSH6, and PMS2). Lynch syndrome is characterized by early-onset colorectal cancer. Patients with Lynch syndrome are also prone to develop other types of cancers, including endometrial, gastric, renal, ureteral, and small intestinal cancers. ${ }^{44}$ Lifetime risk of pancreatic cancer in patients with Lynch syndrome is $3.7 \%$ up to the age of 70, which is an 8.6-fold increased risk compared to the general population. ${ }^{45}$

\section{Familial Breast-Ovarian Cancer}

Familial breast-ovarian cancer syndrome is an autosomal dominantly inherited syndrome associated with germline mutations in $B R C A 1$ and $B R C A 2$ tumor-suppressor genes involved in repair of DNA damage. Carriers of the gene mutations are at a high risk for developing early-onset breast and ovarian cancers, as well as cancers of the gallbladder and bile duct (RR 4.97), prostate (RR 4.65), stomach (RR 2.59), and malignant melanoma (RR 2.58). ${ }^{46} B R C A 1$ mutation is associated with a 2.3 -fold to 3.6 -fold increased risk for pancreatic cancer, ${ }^{47,48}$ and $B R C A 2$ mutation is associated with a 3 -fold to 10 -fold increased risk for pancreatic cancer. ${ }^{46,49,50}$ In patients with sporadic pancreatic cancer, $7.3 \%$ had a germline $B R C A 2$ mutation. ${ }^{51}$ Approximately $1 \%$ of the general Ashkenazi Jewish population carries each of the $B R C A 1$ and $B R C A 2$ founder mutations. ${ }^{52,53}$ Studies have shown that the BRCA2 mutation is found in $5.5 \%$ to $10 \%$ of patients with pancreatic adenocarcinoma who are of Ashkenazi Jewish descent. ${ }^{52-55}$

\section{TARGETS FOR SCREENING AND SURVEILLANCE}

The ideal screening strategy for pancreatic cancer would target high-grade benign noninvasive precursor neoplastic lesions (pancreatic intraepithelial neoplasias [PanINs] or intraductal papillary mucinous neoplasms [IPMNs]) before malignant transformation or at an early stage that would allow for curative surgical resection. ${ }^{56}$ Although IPMNs can be detected as cystic lesions or a dilated main pancreatic duct or both, PanINs are small branch ducts less than $5 \mathrm{~mm}$ in size, often microscopic, and not reliably visualized by clinical imaging tests. Hence, the optimal strategy for detection of early pancreatic neoplasia may need to involve biomarker tests alone or in combination with imaging.

\section{AVAILABLE AND ANTICIPATED TUMOR MARKERS}

Currently, there is no biomarker with adequate sensitivity and specificity that can be used for routine clinical screening. ${ }^{57}$ Given the typical late stage of disease at the time of diagnosis, there has been much effort invested in identifying accurate tumor markers to aid in earlier diagnosis of pancreatic cancer.

The most widely used serum marker in patients with pancreatic cancer is sialylated Lewis blood group antigen on MUC-1 (Mucin 1, cell surface associated), carbohydrate antigen 19-9 (CA 19-9). It is a cell surface glycoprotein expressed by pancreatic cancer cells, but is 
also found in normal pancreatic and biliary duct cells and gastric, colonic, endometrial, and salivary epithelia. ${ }^{58}$ Consequently, CA $19-9$ is not routinely used for diagnosis because of the unacceptably high rate of false-positive results, with specificity ranging from $33 \%$ to $100 \%{ }^{59-61}$ CA $19-9$ is also associated with imperfect sensitivity, ranging from $41 \%$ to $86 \% .59,61$ Approximately $4 \%$ to $15 \%$ of the general population do not express the Lewis antigen and therefore do not have detectable CA 19-9 levels. ${ }^{61-65}$ In patients with resectable pancreatic cancer, only $65 \%$ exhibit an elevated level of CA 19-9. ${ }^{61}$ The marker is also inadequate to differentiate reliably between pancreatic cancer and chronic pancreatitis, as up to $40 \%$ of patient with chronic pancreatitis can exhibit elevated levels of CA 19-9. ${ }^{61,66}$ Given its performance characteristics as a biomarker in the general population, serum CA 19-9 is used primarily for monitoring responses to therapy in patients already diagnosed with cancer, rather than for early diagnosis. ${ }^{61,67-69}$ A recent feasibility study of 546 individuals with one or more FDRs with pancreatic cancer used serum CA19-9 as a screening test. In the 27 patients with elevated CA 19-9 levels, endoscopic ultrasound (EUS) was performed, and one case of asymptomatic pancreatic ductal adenocarcinoma was detected. ${ }^{70}$

Carcinoembryonic antigen (CEA) was the first biomarker used in diagnostics. Several studies have demonstrated high levels of CEA in the pancreatic juice of patients with pancreatic cancer compared to those with benign pancreatic disease. ${ }^{71-74}$ When the CEA cutoff level was set at $50 \mathrm{ng} / \mathrm{mL}$, the positive predictive value, negative predictive value, and accuracy for diagnosing pancreatic cancer were $77 \%, 95 \%$, and $85 \%$, respectively. ${ }^{71,75}$ The main limitation of CEA is its low sensitivity, ranging from $25 \%$ to $56 \%$, with relatively high specificity, ranging from $82 \%$ to $100 \%$ in distinguishing pancreatic cancer from benign pancreatic diseases. $59,76-81$

Much of the initial efforts in identifying novel markers of pancreatic cancer focused on carbohydrate antigens of MUC1 in hopes of improving the performance of CA 19-9. PAM4 is an anti-MUC1 monoclonal antibody that appears to detect MUC1 expressed by pancreatic cancer more specifically than it detects MUC1 antigens derived from other cancers (eg, breast and ovarian). ${ }^{82}$ Further, in comparison with CA 19-9, PAM4 demonstrated higher sensitivity and specificity in discriminating patients with pancreatic cancer from those with chronic pancreatitis $(P<.003) .{ }^{82}$ As expected, patients with advanced disease had significantly higher levels that those with early disease. Diagnostic sensitivity of PAM4 for stage 3 and stage 4 disease was $91 \%$; for stage 2, 86\%; and for stage 1, 62\% (stage 1A, 54\%; stage $1 \mathrm{~B}, 75 \%) .{ }^{83}$ Further supporting the potential role of PAM4 in detecting early-stage pancreatic cancer, PAM4 expression was detected in precursor lesions of pancreatic adenocarcinoma, positive in $89 \%$ of PanINs and $86 \%$ of IMPNs examined, including $94 \%$ of the earliest neoplastic lesions, PanIN-1A and 1B. ${ }^{84}$

Recent studies have identified other potential biomarkers for pancreatic cancer, including CA494, ${ }^{85}$ carcinoembryonic antigen-related cell adhesion molecule 1 (CEACAM1), ${ }^{86}$ parathyroid hormone-related protein (PTHrP), ${ }^{87}$ tumor M2-pyruvate kinase (TuM2-PK), ${ }^{88}$ anti-mucin antibody CAM 17.1, ${ }^{78}$ and serum beta-human chorionic gonadotropin $(\beta-$ HCG) ${ }^{89}$ Although their performance characteristics in initial studies are promising, larger studies are needed to confirm their clinical applicability and they are currently used only in research settings.

Pancreatic juice sample provides a rich medium for genetic and epigenetic marker analysis. Pancreatic juice samples can be obtained at the time of endoscopic ultrasound (secretinstimulated) or endoscopic retrograde cholangiopancreatography (duodenal aspirate ${ }^{90}$ or pure pancreatic juice). ${ }^{57}$ Markers that have been studied in pancreatic juice include K-ras mutations, p53 mutations, DNA methylation aberrations, and mitochondrial DNA 
mutations. ${ }^{61}$ Mutant K-ras is a marker of particular interest because these mutations are present in $90 \%$ of pancreatic adenocarcinomas and it has been measured in pancreatic juice samples. However, its sensitivity and specificity for pancreatic cancer are poor (sensitivity $38 \%-62 \%$; specificity $88 \%-90 \%$ ), most likely because mutant K-ras can also be found in chronic pancreatitis and in PanINs without pancreatic cancer. ${ }^{57,90-96}$ Mutations at $p 53$ are found in approximately $70 \%$ of invasive pancreatic adenocarcinomas ${ }^{91}$ and have been detected in $40 \%$ to $50 \%$ of pancreatic juice samples and brush cytology specimens of patients with pancreatic cancer. ${ }^{97}$ DNA promoter methylation alterations have been investigated in multiple candidate genes, including $p 16,{ }^{98,99} R E L N,{ }^{100} D A B 1,{ }^{100}$ ppENK, ${ }^{101,102}$ Cyclin D2, ${ }^{103}$ SOCS1, ${ }^{104}$ SPARC, ${ }^{105}$ TSLC1, ${ }^{106}$ and others. ${ }^{61,102,107}$ DNA promoter hypermethylation status was quantified in a panel of candidate genes (Cyclin D2, FOXE1, NPTX2, ppENK, p16, and TFP12) in pure pancreatic juice obtained from patients with pancreatic ductal adenocarcinoma, intraductal papillary mucinous neoplasms, chronic pancreatitis, and controls with no known pancreatic disease, as well as a from a cohort of high-risk individuals from FPC kindreds. This method demonstrated high sensitivity (82\%) and specificity $(100 \%)$ in identifying patients with pancreatic cancer. ${ }^{108}$ Mitochondrial DNA mutations are commonly found in multiple cancers. ${ }^{61,109-113}$ Using chip technologies, initial studies appear to suggest that mitochondrial mutations can be reliably detected in pancreatic juice samples from patients with pancreatic cancer. ${ }^{61,111}$

\section{APPROACHES TO SCREENING}

Currently, there is no sufficiently sensitive, specific, and reliable screening test for the early detection of pancreatic cancer. The great majority of pancreatic cancers, accounting for at least $90 \%$ of all patients, are considered sporadic. ${ }^{2-4}$ The detection rate is low in averagerisk individuals because pancreatic cancer is a rare disease, despite its significant death toll. In screening studies performed in Japan, 5 cancers were found in 2511 individuals. ${ }^{114}$ Given the overall low incidence of disease and the current lack of accurate, inexpensive, and noninvasive screening tests, the consensus is that widespread population-based screening for pancreatic cancer in the general population or in those with only one affected FDR is neither feasible nor indicated in most countries. ${ }^{56}$ However, selective screening has been performed in high-risk patients from FPC kindreds and in patients with inherited cancer syndromes. ${ }^{56,115,116}$

The various approaches to screening and results of screening tests for asymptomatic pancreatic neoplasms are summarized in Table 1. One approach is population-based screening, such as that formed in Japan with abdominal ultrasound (with ${ }^{114}$ or without ${ }^{117}$ MRI). A second approach uses a serum biomarker such as serum CA19-9 followed by a pancreatic imaging test. ${ }^{70} \mathrm{~A}$ third approach uses only abdominal imaging tests, such as computed tomography (CT), magnetic resonance imaging (MRI), EUS, or endoscopic retrograde cholangiopancreatography (ERCP), in combination or in sequence (ie, EUS after MRI or magnetic resonance cholangiopancreatography [MRCP], or CT if abnormal).

Multidetector computed tomography (MDCT) is currently the abdominal imaging test of choice for pancreatic disease, particularly for diagnosis of solid tumors and staging of pancreatic cancer. ${ }^{118,119}$ Despite its high accuracy for detecting and staging of pancreatic malignancies, the sensitivity of MDCT may be suboptimal, as MDCT misses lesions when used for screening for early pancreatic neoplasia. ${ }^{115,116,119}$ The sensitivity of thin-section, triple-phase helical CT to detect lesions smaller than $2 \mathrm{~cm}$ is only $70 \%$ to $80 \%{ }^{56,120}$ Recent studies have shown that MDCT has a negative predictive value of $87 \%$ for tumor resectability ${ }^{121}$ and an accuracy rate of $85 \%$ to $95 \%{ }^{75,122,123}$ Further, there is also a concern for radiation exposure if $\mathrm{CT}$ is used as part of a long-term screening or surveillance program, particularly in individuals with impaired DNA mismatch repair gene function due 
to $B R C A 1, B R C A 2$, or $P A L B 2$ gene mutation. Hence, CT is not the ideal screening or surveillance imaging test for high-risk individuals. Further, MDCP with a pancreatic protocol may not be as sensitive as EUS in at-risk individuals from FPC kindreds ${ }^{115,116,124}$ (Canto MI, Hruban RH, Fishman EK, et al. Screening for prevalent early pancreatic neoplasia in high risk individuals: a prospective multicenter blinded study of EUS, CT, and MRI. Submitted for publication).

MRI may be an appropriate choice for noninvasive screening of high-risk patients because it is able to image the entire abdomen and pelvis, unlike EUS, while avoiding radiation exposure, unlike CT. MRCP is able to image pancreatic ductal anatomy noninvasively (unlike ERCP) and small cystic lesions such as IPMNs. Preliminary data from high-risk patients who underwent surgical resection suggest that MRI/MRCP may be superior to CT, particularly for detection of IPMNs $(71 \%$ vs $14 \%, P<.0001) .{ }^{56,124}$ A prospective MRI-based screening study of 79 patients aged 39 to 72 years with a $p 16$ Leiden mutation, which is associated with familial atypical multiple mole melanoma syndrome, has shown that earlystage pancreatic cancers can be detected at baseline and during follow-up. ${ }^{125}$ After a median follow-up period of 4 years (range, $0-10$ years), pancreatic cancer was diagnosed in seven patients (9\%). The mean age at diagnosis was 59 years (range, 49-72 years). Three of the asymptomatic pancreatic cancers were present at the first examination, and four were detected after a negative result in the initial examination. All seven patients with cancer had resectable lesions; five underwent surgery, three had an R0 resection, and two had lymph node metastases. Further, possible precursor lesions (ie, duct ectasias or branch-duct IPMNs, based on MRCP) were found in nine individuals (11\%).

EUS has been used to screen high-risk individuals in several screening programs. ${ }^{60,115,116,126,127}$ It can provide high-resolution images of the pancreas without the risk of radiation exposure and can image mural nodules (focal thickening of the wall in branch duct IMPNs), which are associated with increased risk of malignancy. ${ }^{57,119,128}$ The disadvantages of EUS are that it is operator dependent and is an endoscopic procedure with the inherent risks of procedure and sedation, which may limit its role in a widespread screening and surveillance program. Preliminary analysis of high-risk individuals enrolled in a screening program who underwent surgical resection suggests that EUS can detect almost twice as many neoplastic lesions as CT or MRI/MRCP. ${ }^{56,124}$ Published studies using EUSbased screening for high-risk individuals have reported detection of asymptomatic precancerous branch duct IPMNs, large PanINs, incidental pancreatic endocrine tumors, and ductal adenocarcinomas. One Dutch study of $B R C A 1, B R C A 2$, or $p 16$ germline mutation carriers, patients with Peutz-Jeghers syndrome, and relatives of patients reported a high onetime yield of EUS-based screening. The authors found a $6.8 \%$ prevalence $(n=3$ of 44 individuals screened) of asymptomatic pancreatic ductal adenocarcinomas (12, 20, and 50 $\mathrm{mm}$ in size). ${ }^{126}$ All cancers were completely resected but two already had lymph node metastases at presentation. Further, the diagnostic yield of EUS-based screening for prevalent precursor branch duct IPMNs was $16 \%$.

The clinical utility of ancillary studies such as fine-needle aspiration (FNA) and ERCP is not clear. EUS-guided FNA has been used to investigate pancreatic cystic lesions and can provide a cytologic diagnosis of IPMN in $71 \%$ of the cases. ${ }^{129}$ The need for routine FNA of pancreatic cysts in a high-risk population has not been proven, given that the majority of cystic lesions detected are typically small branch duct IPMNs that do not require surgical treatment. EUS-guided FNA can also lead to false-positive results if cytologic aspirates show severe dysplasia or findings suspicious for ductal adenocarcinoma, which can lead to potentially unnecessary surgery. ${ }^{115}$ ERCP has been used routinely in high-risk patients from FPC kindreds with abnormal EUS, but this resulted in a post-ERCP pancreatitis rate of 7\% in one study. ${ }^{115}$ Further, ERCP did not reliably demonstrate ductal communication of 
branch duct IPMNs or lead to additional clinically relevant imaging findings. Hence, most formal screening programs around the world do not recommend routine ERCP for asymptomatic individuals.

\section{SUMMARY}

Accumulating data indicate that clinically available abdominal imaging tests such as EUS and MRI/MRCP can detect asymptomatic precursor benign (IPMN, PanIN) and invasive malignant pancreatic neoplasms, such as ductal adenocarcinoma, in individuals with an inherited predisposition. These asymptomatic FPCs detected have been more likely to be resectable, compared to symptomatic tumors. The most challenging part of screening highrisk individuals is the selection of individuals with high-grade precursor neoplasms for preventive treatment (ie, surgical resection before development of invasive cancer). Ongoing and future research should focus on formulating and validating a model for FPC risk and neoplastic progression using patient characteristics, imaging, and biomarkers. The comparative cost and effectiveness of various approaches for screening and surveillance of high-risk individuals also deserves study. For now, screening is best performed in high-risk individuals within the research protocols in academic centers with multidisciplinary teams with expertise in genetics, gastroenterology, radiology, surgery, and pathology.

\section{References}

1. American Cancer Society. [Accessed September 1, 2011] Cancer facts and figures. 2011. Available at: http://www.cancer.org/acs/groups/content/epidemiologysurveilance/documents/document/ acspc-029771.pdf

2. Lynch HT, Smyrk T, Kern SE, et al. Familial pancreatic cancer: a review. Semin Oncol. 1996; 23:251-75. [PubMed: 8623061]

3. Brand RE, Lynch HT. Hereditary pancreatic adenocarcinoma: a clinical perspective. Med Clin North Am. 2000; 84:665-75. [PubMed: 10872423]

4. Klein AP, Hruban RH, Brune KA, et al. Familial pancreatic cancer. Cancer J. 2001; 7:266-73. [PubMed: 11561603]

5. Lynch HT, Krush AJ, Larsen AL. Heredity and multiple primary malignant neoplasms: six cancer families. Am J Med Sci. 1967; 254:322-9. [PubMed: 6054534]

6. Brune KA, Lau B, Palmisano E, et al. Importance of age of onset in pancreatic cancer kindreds. J Natl Cancer Inst. 2010; 102:119-26. [PubMed: 20068195]

7. Jones S, Hruban RH, Kamiyama M, et al. Exomic sequencing identifies $P A L B 2$ as a pancreatic cancer susceptibility gene. Science. 2009; 324:217. [PubMed: 19264984]

8. Klein AP, Brune KA, Petersen GM, et al. Prospective risk of pancreatic cancer in familial pancreatic cancer kindreds. Cancer Res. 2004; 64:2634-8. [PubMed: 15059921]

9. Slater EP, Langer P, Niemczyk E, et al. $P A L B 2$ mutations in European familial pancreatic cancer families. Clin Genet. 2010; 78:490-4. [PubMed: 20412113]

10. Klein AP, Beaty TH, Bailey-Wilson JE, et al. Evidence for a major gene influencing risk of pancreatic cancer. Genet Epidemiol. 2002; 23:133-49. [PubMed: 12214307]

11. Banke MG, Mulvihill JJ, Aston CE. Inheritance of pancreatic cancer in pancreatic cancer-prone families. Med Clin North Am. 2000; 84:677-90. x-xi. [PubMed: 10872424]

12. Rulyak SJ, Lowenfels AB, Maisonneuve P, et al. Risk factors for the development of pancreatic cancer in familial pancreatic cancer kindreds. Gastroenterology. 2003; 124:1292-9. [PubMed: 12730869]

13. Rieder H, Sina-Frey M, Ziegler A, et al. German national case collection of familial pancreatic cancer-clinical-genetic analysis of the first 21 families. Onkologie. 2002; 25:262-6. [PubMed: 12119461]

14. Pogue-Geile KL, Chen R, Bronner MP, et al. Palladin mutation causes familial pancreatic cancer and suggests a new cancer mechanism. PLoS Med. 2006; 3:e516. [PubMed: 17194196] 
15. Zogopoulos G, Rothenmund H, Eppel A, et al. The P239S palladin variant does not account for a significant fraction of hereditary or early onset pancreas cancer. Hum Genet. 2007; 121:635-7. [PubMed: 17415588]

16. Slater E, Amrillaeva V, Fendrich V, et al. Palladin mutation causes familial pancreatic cancer: absence in European families. PLoS Med. 2007; 4:e164. [PubMed: 17455999]

17. Klein AP, de Andrade M, Hruban RH, et al. Linkage analysis of chromosome 4 in families with familial pancreatic cancer. Cancer Biol Ther. 2007; 6:320-3. [PubMed: 17312386]

18. Earl J, Yan L, Vitone LJ, et al. Evaluation of the 4q32-34 locus in European familial pancreatic cancer. Cancer Epidemiol Biomarkers Prev. 2006; 15:1948-55. [PubMed: 17035404]

19. Salaria SN, Illei P, Sharma R, et al. Palladin is overexpressed in the non-neoplastic stroma of infiltrating ductal adenocarcinomas of the pancreas, but is only rarely overexpressed in neoplastic cells. Cancer Biol Ther. 2007; 6:324-8. [PubMed: 17404500]

20. Murphy KM, Brune KA, Griffin C, et al. Evaluation of candidate genes MAP2K4, MADH4, $A C V R 1 B$, and BRCA2 in familial pancreatic cancer: deleterious BRCA2 mutations in $17 \%$. Cancer Res. 2002; 62:3789-93. [PubMed: 12097290]

21. Hahn SA, Greenhalf B, Ellis I, et al. BRCA2 germline mutations in familial pancreatic carcinoma. J Natl Cancer Inst. 2003; 95:214-21. [PubMed: 12569143]

22. Couch FJ, Johnson MR, Rabe KG, et al. The prevalence of BRCA2 mutations in familial pancreatic cancer. Cancer Epidemiol Biomarkers Prev. 2007; 16:342-6. [PubMed: 17301269]

23. Greer JB, Brand RE. New developments in pancreatic cancer. Curr Gastroenterol Rep. 13:131-9. [PubMed: 21258973]

24. Stadler ZK, Salo-Mullen E, Sabbaghian N, et al. Germline PALB2 mutation analysis in breastpancreas cancer families. J Med Genet. 2011; 48:523-5. [PubMed: 21415078]

25. Hofstatter EW, Domchek SM, Miron A, et al. PALB2 mutations in familial breast and pancreatic cancer. Fam Cancer. 2011; 10:225-31. [PubMed: 21365267]

26. Grover S, Syngal S. Hereditary pancreatic cancer. Gastroenterology. 2010; 139:1076-80. 1080, e1-2. [PubMed: 20727885]

27. Lowenfels AB, Maisonneuve P, Whitcomb DC. Risk factors for cancer in hereditary pancreatitis. International Hereditary Pancreatitis Study Group Med Clin North Am. 2000; 84:565-73.

28. Teich N, Nemoda Z, Kohler H, et al. Gene conversion between functional trypsinogen genes PRSS1 and PRSS2 associated with chronic pancreatitis in a six-year-old girl. Hum Mutat. 2005; 25:343-7. [PubMed: 15776435]

29. Teich N, Rosendahl J, Toth M, et al. Mutations of human cationic trypsinogen (PRSSI) and chronic pancreatitis. Hum Mutat. 2006; 27:721-30. [PubMed: 16791840]

30. Sahin-Toth M, Toth M. Gain-of-function mutations associated with hereditary pancreatitis enhance autoactivation of human cationic trypsinogen. Biochem Biophys Res Commun. 2000; 278:286-9. [PubMed: 11097832]

31. Whitcomb DC, Ulrich CD 2nd. Hereditary pancreatitis: new insights, new directions. Baillieres Best Pract Res Clin Gastroenterol. 1999; 13:253-63. [PubMed: 11030605]

32. Lowenfels AB, Maisonneuve P, DiMagno EP, et al. International Hereditary Pancreatitis Study Group. Hereditary pancreatitis and the risk of pancreatic cancer. J Natl Cancer Inst. 1997; 89:4426. [PubMed: 9091646]

33. Howes N, Lerch MM, Greenhalf W, et al. Clinical and genetic characteristics of hereditary pancreatitis in Europe. Clin Gastroenterol Hepatol. 2004; 2:252-61. [PubMed: 15017610]

34. Lowenfels AB, Maisonneuve P, Whitcomb DC, et al. Cigarette smoking as a risk factor for pancreatic cancer in patients with hereditary pancreatitis. JAMA. 2001; 286:169-70. [PubMed: 11448279]

35. Latchford A, Greenhalf W, Vitone LJ, et al. Peutz-Jeghers syndrome and screening for pancreatic cancer. Br J Surg. 2006; 93:1446-55. [PubMed: 17115408]

36. Gruber SB, Entius MM, Petersen GM, et al. Pathogenesis of adenocarcinoma in Peutz-Jeghers syndrome. Cancer Res. 1998; 58:5267-70. [PubMed: 9850045]

37. Giardiello FM, Brensinger JD, Tersmette AC, et al. Very high risk of cancer in familial PeutzJeghers syndrome. Gastroenterology. 2000; 119:1447-53. [PubMed: 11113065] 
38. Lynch HT, Fusaro RM, Sandberg AA, et al. Chromosome instability and the FAMMM syndrome. Cancer Genet Cytogenet. 1993; 71:27-39. [PubMed: 8275450]

39. Haluska FG, Hodi FS. Molecular genetics of familial cutaneous melanoma. J Clin Oncol. 1998; 16:670-82. [PubMed: 9469357]

40. Soufir N, Avril MF, Chompret A, et al. The French Familial Melanoma Study Group. Prevalence of $p 16$ and $C D K 4$ germline mutations in 48 melanoma-prone families in France. Hum Mol Genet. 1998; 7:209-16. [PubMed: 9425228]

41. Lynch HT, Brand RE, Hogg D, et al. Phenotypic variation in eight extended $C D K N 2 A$ germline mutation familial atypical multiple mole melanoma-pancreatic carcinoma-prone families: the familial atypical mole melanoma-pancreatic carcinoma syndrome. Cancer. 2002; 94:84-96. [PubMed: 11815963]

42. Lynch HT, Fusaro RM, Lynch JF, et al. Pancreatic cancer and the FAMMM syndrome. Fam Cancer. 2008; 7:103-12. [PubMed: 17992582]

43. Goldstein AM, Fraser MC, Struewing JP, et al. Increased risk of pancreatic cancer in melanomaprone kindreds with p16INK4 mutations. N Engl J Med. 1995; 333:970-4. [PubMed: 7666916]

44. Geary J, Sasieni P, Houlston R, et al. Gene-related cancer spectrum in families with hereditary non-polyposis colorectal cancer (HNPCC). Fam Cancer. 2008; 7:163-72. [PubMed: 17939062]

45. Kastrinos F, Mukherjee B, Tayob N, et al. Risk of pancreatic cancer in families with Lynch syndrome. JAMA. 2009; 302:1790-5. [PubMed: 19861671]

46. The Breast Cancer Linkage Consortium. Cancer risks in BRCA2 mutation carriers. J Natl Cancer Inst. 1999; 91:1310-6. [PubMed: 10433620]

47. Brose MS, Rebbeck TR, Calzone KA, et al. Cancer risk estimates for BRCA1 mutation carriers identified in a risk evaluation program. J Natl Cancer Inst. 2002; 94:1365-72. [PubMed: 12237282]

48. Thompson D, Easton DF. Cancer incidence in BRCA1 mutation carriers. J Natl Cancer Inst. 2002; 94:1358-65. [PubMed: 12237281]

49. Lal G, Liu G, Schmocker B, et al. Inherited predisposition to pancreatic adenocarcinoma: role of family history and germ-line $p 16, B R C A 1$, and BRCA2 mutations. Cancer Res. 2000; 60:409-16. [PubMed: 10667595]

50. van Asperen CJ, Brohet RM, Meijers-Heijboer EJ, et al. Cancer risks in BRCA2 families: estimates for sites other than breast and ovary. J Med Genet. 2005; 42:711-9. [PubMed: 16141007]

51. Goggins M, Schutte M, Lu J, et al. Germline BRCA2 gene mutations in patients with apparently sporadic pancreatic carcinomas. Cancer Res. 1996; 56:5360-4. [PubMed: 8968085]

52. Struewing JP, Abeliovich D, Peretz T, et al. The carrier frequency of the BRCA1 185delAG mutation is approximately 1 percent in Ashkenazi Jewish individuals. Nat Genet. 1995; 11:198200. [PubMed: 7550349]

53. Hartge P, Struewing JP, Wacholder $\mathrm{S}$, et al. The prevalence of common BRCA1 and BRCA2 mutations among Ashkenazi Jews. Am J Hum Genet. 1999; 64:963-70. [PubMed: 10090881]

54. Ozcelik H, Schmocker B, Di Nicola N, et al. Germline BRCA2 6174delT mutations in Ashkenazi Jewish pancreatic cancer patients. Nat Genet. 1997; 16:17-8. [PubMed: 9140390]

55. Roa BB, Boyd AA, Volcik K, et al. Ashkenazi Jewish population frequencies for common mutations in BRCA1 and BRCA2. Nat Genet. 1996; 14:185-7. [PubMed: 8841191]

56. Steinberg WM, Barkin JS, Bradley EL 3rd, et al. Should patients with a strong family history of pancreatic cancer be screened on a periodic basis for cancer of the pancreas? Pancreas. 2009; 38:e137-50. [PubMed: 19550273]

57. Canto MI. Strategies for screening for pancreatic adenocarcinoma in high-risk patients. Semin Oncol. 2007; 34:295-302. [PubMed: 17674957]

58. Vitone LJ, Greenhalf W, McFaul CD, et al. The inherited genetics of pancreatic cancer and prospects for secondary screening. Best Pract Res Clin Gastroenterol. 2006; 20:253-83. [PubMed: 16549327]

59. Bunger S, Laubert T, Roblick UJ, et al. Serum biomarkers for improved diagnostic of pancreatic cancer: a current overview. J Cancer Res Clin Oncol. 2011; 137:375-89. [PubMed: 21193998] 
60. Brentnall TA, Bronner MP, Byrd DR, et al. Early diagnosis and treatment of pancreatic dysplasia in patients with a family history of pancreatic cancer. Ann Intern Med. 1999; 131:247-55. [PubMed: 10454945]

61. Goggins M. Identifying molecular markers for the early detection of pancreatic neoplasia. Semin Oncol. 2007; 34:303-10. [PubMed: 17674958]

62. Ritts RE, Pitt HA. CA 19-9 in pancreatic cancer. Surg Oncol Clin N Am. 1998; 7:93-101. [PubMed: 9443988]

63. Safi F, Schlosser W, Falkenreck S, et al. CA 19-9 serum course and prognosis of pancreatic cancer. Int J Pancreatol. 1996; 20:155-61. [PubMed: 9013275]

64. Tian F, Appert HE, Myles J, et al. Prognostic value of serum CA 19-9 levels in pancreatic adenocarcinoma. Ann Surg. 1992; 215:350-5. [PubMed: 1348409]

65. Mann DV, Edwards R, Ho S, et al. Elevated tumour marker CA19-9: clinical interpretation and influence of obstructive jaundice. Eur J Surg Oncol. 2000; 26:474-9. [PubMed: 11016469]

66. Rosty C, Goggins M. Early detection of pancreatic carcinoma. Hematol Oncol Clin North Am. 2002; 16:37-52. [PubMed: 12063828]

67. DiMagno EP, Reber HA, Tempero MA. American Gastroenterological Association. AGA technical review on the epidemiology, diagnosis, and treatment of pancreatic ductal adenocarcinoma. Gastroenterology. 1999; 117:1464-84. [PubMed: 10579989]

68. Steinberg W. The clinical utility of the CA 19-9 tumor-associated antigen. Am J Gastroenterol. 1990; 85:350-5. [PubMed: 2183589]

69. Lamerz R. Role of tumour markers, cytogenetics. Ann Oncol. 1999; 10(Suppl 4):145-9. [PubMed: 10436809]

70. Zubarik R, Gordon SR, Lidofsky SD, et al. Screening for pancreatic cancer in a high-risk population with serum CA 19-9 and targeted EUS: a feasibility study. Gastrointest Endosc. 2011; 74:87-95. [PubMed: 21704809]

71. Futakawa N, Kimura W, Yamagata S, et al. Significance of K-ras mutation and CEA level in pancreatic juice in the diagnosis of pancreatic cancer. J Hepatobiliary Pancreat Surg. 2000; 7:6371. [PubMed: 10982594]

72. Basso D, Fabris C, Del Favero G, et al. Serum carcinoembryonic antigen in the differential diagnosis of pancreatic cancer: influence of tumour spread, liver impairment, and age. Dis Markers. 1988; 6:203-7. [PubMed: 3168400]

73. Chevinsky AH. CEA in tumors of other than colorectal origin. Semin Surg Oncol. 1991; 7:162-6. [PubMed: 2068450]

74. Ona FV, Zamcheck N, Dhar P, et al. Carcinoembryonic antigen (CEA) in the diagnosis of pancreatic cancer. Cancer. 1973; 31:324-7. [PubMed: 4687879]

75. Sharma C, Eltawil KM, Renfrew PD, et al. Advances in diagnosis, treatment and palliation of pancreatic carcinoma: 1990-2010. World J Gastroenterol. 2011; 17:867-97. [PubMed: 21412497]

76. Duraker N, Hot S, Polat Y, et al. CEA, CA 19-9, and CA 125 in the differential diagnosis of benign and malignant pancreatic diseases with or without jaundice. J Surg Oncol. 2007; 95:142-7. [PubMed: 17262731]

77. Ehmann M, Felix K, Hartmann D, et al. Identification of potential markers for the detection of pancreatic cancer through comparative serum protein expression profiling. Pancreas. 2007; 34:205-14. [PubMed: 17312459]

78. Gansauge F, Gansauge S, Parker N, et al. CAM 17. 1-a new diagnostic marker in pancreatic cancer. Br J Cancer. 1996; 74:1997-2002. [PubMed: 8980403]

79. Groblewska M, Mroczko B, Wereszczynska-Siemiatkowska U, et al. Serum levels of granulocyte colony-stimulating factor (G-CSF) and macrophage colony-stimulating factor (M-CSF) in pancreatic cancer patients. Clin Chem Lab Med. 2007; 45:30-4. [PubMed: 17243911]

80. Liao WC, Wu MS, Wang HP, et al. Serum heat shock protein 27 is increased in chronic pancreatitis and pancreatic carcinoma. Pancreas. 2009; 38:422-6. [PubMed: 19214136]

81. Mroczko B, Lukaszewicz-Zajac M, Wereszczynska-Siemiatkowska U, et al. Clinical significance of the measurements of serum matrix metalloproteinase- 9 and its inhibitor (tissue inhibitor of metalloproteinase-1) in patients with pancreatic cancer: metalloproteinase- 9 as an independent prognostic factor. Pancreas. 2009; 38:613-8. [PubMed: 19629003] 
82. Gold DV, Modrak DE, Ying Z, et al. New MUC1 serum immunoassay differentiates pancreatic cancer from pancreatitis. J Clin Oncol. 2006; 24:252-8. [PubMed: 16344318]

83. Gold DV, Goggins M, Modrak DE, et al. Detection of early-stage pancreatic adeno-carcinoma. Cancer Epidemiol Biomarkers Prev. 2010; 19:2786-94. [PubMed: 20810605]

84. Gold DV, Karanjawala Z, Modrak DE, et al. PAM4-reactive MUC1 is a biomarker for early pancreatic adenocarcinoma. Clin Cancer Res. 2007; 13:7380-7. [PubMed: 18094420]

85. Friess H, Buchler M, Auerbach B, et al. CA 494-a new tumor marker for the diagnosis of pancreatic cancer. Int J Cancer. 1993; 53:759-63. [PubMed: 8449599]

86. Simeone DM, Ji B, Banerjee M, et al. CEACAM1, a novel serum biomarker for pancreatic cancer. Pancreas. 2007; 34:436-43. [PubMed: 17446843]

87. Bouvet M, Nardin SR, Burton DW, et al. Parathyroid hormone-related protein as a novel tumor marker in pancreatic adenocarcinoma. Pancreas. 2002; 24:284-90. [PubMed: 11893937]

88. Kumar Y, Gurusamy K, Pamecha V, et al. Tumor M2-pyruvate kinase as tumor marker in exocrine pancreatic cancer a meta-analysis. Pancreas. 2007; 35:114-9. [PubMed: 17632316]

89. Louhimo J, Alfthan H, Stenman UH, et al. Serum HCG beta and CA 72-4 are stronger prognostic factors than CEA, CA 19-9 and CA 242 in pancreatic cancer. Oncology. 2004; 66:126-31. [PubMed: 15138364]

90. Watanabe $\mathrm{H}, \mathrm{Ha} \mathrm{A}, \mathrm{Hu} \mathrm{YX}$, et al. K-ras mutations in duodenal aspirate without secretin stimulation for screening of pancreatic and biliary tract carcinoma. Cancer. 1999; 86:1441-8. [PubMed: 10526271]

91. Caldas C, Hahn SA, da Costa LT, et al. Frequent somatic mutations and homozygous deletions of the (p16 MTS1) gene in pancreatic adenocarcinoma. Nat Genet. 1994; 8:27-32. [PubMed: 7726912]

92. Trumper L, Menges M, Daus H, et al. Low sensitivity of the ki-ras polymerase chain reaction for diagnosing pancreatic cancer from pancreatic juice and bile: a multi-center prospective trial. J Clin Oncol. 2002; 20:4331-7. [PubMed: 12409332]

93. Berger DH, Chang H, Wood M, et al. Mutational activation of K-ras in nonneoplastic exocrine pancreatic lesions in relation to cigarette smoking status. Cancer. 1999; 85:326-32. [PubMed: 10023699]

94. Kalthoff $\mathrm{H}$, Schmiegel $\mathrm{W}$, Roeder $\mathrm{C}$, et al. $p 53$ and $\mathrm{K}-R A S$ alterations in pancreatic epithelial cell lesions. Oncogene. 1993; 8:289-98. [PubMed: 8426738]

95. Schutte M, Hruban RH, Geradts J, et al. Abrogation of the Rb/p16 tumor-suppressive pathway in virtually all pancreatic carcinomas. Cancer Res. 1997; 57:3126-30. [PubMed: 9242437]

96. Tada M, Komatsu Y, Kawabe T, et al. Quantitative analysis of K-ras gene mutation in pancreatic tissue obtained by endoscopic ultrasonography-guided fine needle aspiration: clinical utility for diagnosis of pancreatic tumor. Am J Gastroenterol. 2002; 97:2263-70. [PubMed: 12358243]

97. Sturm PD, Hruban RH, Ramsoekh TB, et al. The potential diagnostic use of K-ras codon 12 and p53 alterations in brush cytology from the pancreatic head region. J Pathol. 1998; 186:247-53. [PubMed: 10211112]

98. Sato N, Goggins M. The role of epigenetic alterations in pancreatic cancer. J Hepatobiliary Pancreat Surg. 2006; 13:286-95. [PubMed: 16858539]

99. Sato N, Ueki T, Fukushima N, et al. Aberrant methylation of $\mathrm{CpG}$ islands in intraductal papillary mucinous neoplasms of the pancreas. Gastroenterology. 2002; 123:365-72. [PubMed: 12105864]

100. Sato N, Fukushima N, Chang R, et al. Differential and epigenetic gene expression profiling identifies frequent disruption of the RELN pathway in pancreatic cancers. Gastroenterology. 2006; 130:548-65. [PubMed: 16472607]

101. Fukushima N, Walter KM, Uek T, et al. Diagnosing pancreatic cancer using methylation specific PCR analysis of pancreatic juice. Cancer Biol Ther. 2003; 2:78-83. [PubMed: 12673124]

102. Ueki T, Walter KM, Skinner H, et al. Aberrant $\mathrm{CpG}$ island methylation in cancer cell lines arises in the primary cancers from which they were derived. Oncogene. 2002; 21:2114-7. [PubMed: 11960385]

103. Matsubayashi H, Sato N, Fukushima N, et al. Methylation of cyclin D2 is observed frequently in pancreatic cancer but is also an age-related phenomenon in gastrointestinal tissues. Clin Cancer Res. 2003; 9:1446-52. [PubMed: 12684418] 
104. Fukushima N, Sato N, Sahin F, et al. Aberrant methylation of suppressor of cytokine signalling-1 (SOCS-1) gene in pancreatic ductal neoplasms. Br J Cancer. 2003; 89:338-43. [PubMed: 12865927]

105. Sato N, Fukushima N, Maehara N, et al. SPARC/osteonectin is a frequent target for aberrant methylation in pancreatic adenocarcinoma and a mediator of tumor-stromal interactions. Oncogene. 2003; 22:5021-30. [PubMed: 12902985]

106. Jansen M, Fukushima N, Rosty C, et al. Aberrant methylation of the $5^{\prime}$ CpG island of TSLC1 is common in pancreatic ductal adenocarcinoma and is first manifest in high-grade PanlNs. Cancer Biol Ther. 2002; 1:293-6. [PubMed: 12432281]

107. Sato N, Fukushima N, Maitra A, et al. Discovery of novel targets for aberrant methylation in pancreatic carcinoma using high-throughput microarrays. Cancer Res. 2003; 63:3735-42. [PubMed: 12839967]

108. Matsubayashi H, Canto M, Sato N, et al. DNA methylation alterations in the pancreatic juice of patients with suspected pancreatic disease. Cancer Res. 2006; 66:1208-17. [PubMed: 16424060]

109. Polyak K, Li Y, Zhu H, et al. Somatic mutations of the mitochondrial genome in human colorectal tumours. Nat Genet. 1998; 20:291-3. [PubMed: 9806551]

110. Jones JB, Song JJ, Hempen PM, et al. Detection of mitochondrial DNA mutations in pancreatic cancer offers a "mass"-ive advantage over detection of nuclear DNA mutations. Cancer Res. 2001; 61:1299-304. [PubMed: 11245424]

111. Maitra A, Cohen Y, Gillespie SE, et al. The Human MitoChip: a high-throughput sequencing microarray for mitochondrial mutation detection. Genome Res. 2004; 14:812-9. [PubMed: 15123581]

112. Fliss MS, Usadel H, Caballero OL, et al. Facile detection of mitochondrial DNA mutations in tumors and bodily fluids. Science. 2000; 287:2017-9. [PubMed: 10720328]

113. Sanchez-Cespedes M, Parrella P, Nomoto S, et al. Identification of a mononucleotide repeat as a major target for mitochondrial DNA alterations in human tumors. Cancer Res. 2001; 61:7015-9. [PubMed: 11585726]

114. Kuroki-Suzuki S, Kuroki Y, Nasu K, et al. Pancreatic cancer screening employing noncontrast magnetic resonance imaging combined with ultrasonography. Jpn J Radiol. 2011; 29:265-71. [PubMed: 21607840]

115. Canto MI, Goggins M, Hruban RH, et al. Screening for early pancreatic neoplasia in high-risk individuals: a prospective controlled study. Clin Gastroenterol Hepatol. 2006; 4:766-81. [quiz 665]. [PubMed: 16682259]

116. Canto MI, Goggins M, Yeo CJ, et al. Screening for pancreatic neoplasia in high-risk individuals: an EUS-based approach. Clin Gastroenterol Hepatol. 2004; 2:606-21. [PubMed: 15224285]

117. Ikeda M, Sato T, Morozumi A, et al. Morphologic changes in the pancreas detected by screening ultrasonography in a mass survey, with special reference to main duct dilatation, cyst formation, and calcification. Pancreas. 1994; 9:508-12. [PubMed: 7937699]

118. American Gastroenterological Association. Medical position statement: epidemiology, diagnosis, and treatment of pancreatic ductal adenocarcinoma. Gastroenterology. 1999; 117:1463-84. [PubMed: 10579988]

119. Canto MI. Screening and surveillance approaches in familial pancreatic cancer. Gastrointest Endosc Clin N Am. 2008; 18:535-53. x. [PubMed: 18674702]

120. Bronstein YL, Loyer EM, Kaur H, et al. Detection of small pancreatic tumors with multiphasic helical CT. Am J Roentgenol. 2004; 182:619-23. [PubMed: 14975959]

121. Vargas R, Nino-Murcia M, Trueblood W, et al. MDCT in pancreatic adenocarcinoma: prediction of vascular invasion and resectability using a multiphasic technique with curved planar reformations. Am J Roentgenol. 2004; 182:419-25. [PubMed: 14736675]

122. Diehl SJ, Lehmann KJ, Sadick M, et al. Pancreatic cancer: value of dual-phase helical CT in assessing resectability. Radiology. 1998; 206:373-8. [PubMed: 9457188]

123. Lu DS, Reber HA, Krasny RM, et al. Local staging of pancreatic cancer: criteria for unresectability of major vessels as revealed by pancreatic-phase, thin-section helical CT. Am J Roentgenol. 1997; 168:1439-43. [PubMed: 9168704] 
124. Canto MI, Schulick RD, Goggins MG, et al. Preoperative detection of familial pancreatic neoplasms by endoscopic ultrasonography (EUS), multidetector computed tomography (CT), and/or magnetic resonance cholangiopancreatography (MRCP). Gastrointest Endosc. 2008; 67:AB225.

125. Vasen HF, Wasser M, van Mil A, et al. Magnetic resonance imaging surveillance detects earlystage pancreatic cancer in carriers of a p16-Leiden mutation. Gastroenterology. 2011; 140:850-6. [PubMed: 21129377]

126. Poley JW, Kluijt I, Gouma DJ, et al. The yield of first-time endoscopic ultrasonography in screening individuals at a high risk of developing pancreatic cancer. Am J Gastroenterol. 2009; 104:2175-81. [PubMed: 19491823]

127. Brentnall TA. Cancer surveillance of patients from familial pancreatic cancer kindreds. Med Clin North Am. 2000; 84:707-18. [PubMed: 10872427]

128. Tanaka M, Chari S, Adsay V, et al. International consensus guidelines for management of intraductal papillary mucinous neoplasms and mucinous cystic neoplasms of the pancreas. Pancreatology. 2006; 6:17-32. [PubMed: 16327281]

129. Emerson RE, Randolph ML, Cramer HM. Endoscopic ultrasound-guided fine-needle aspiration cytology diagnosis of intraductal papillary mucinous neoplasm of the pancreas is highly predictive of pancreatic neoplasia. Diagn Cytopathol. 2006; 34:457-62. [PubMed: 16783773]

130. Ludwig E, Olson SH, Bayuga S, et al. Feasibility and yield of screening in relatives from familial pancreatic cancer families. Am J Gastroenterol. 2011; 106:946-54. [PubMed: 21468009]

131. Verna EC, Hwang C, Stevens PD, et al. Pancreatic cancer screening in a prospective cohort of high-risk patients: a comprehensive strategy of imaging and genetics. Clin Cancer Res. 2010; 16:5028-37. [PubMed: 20876795] 


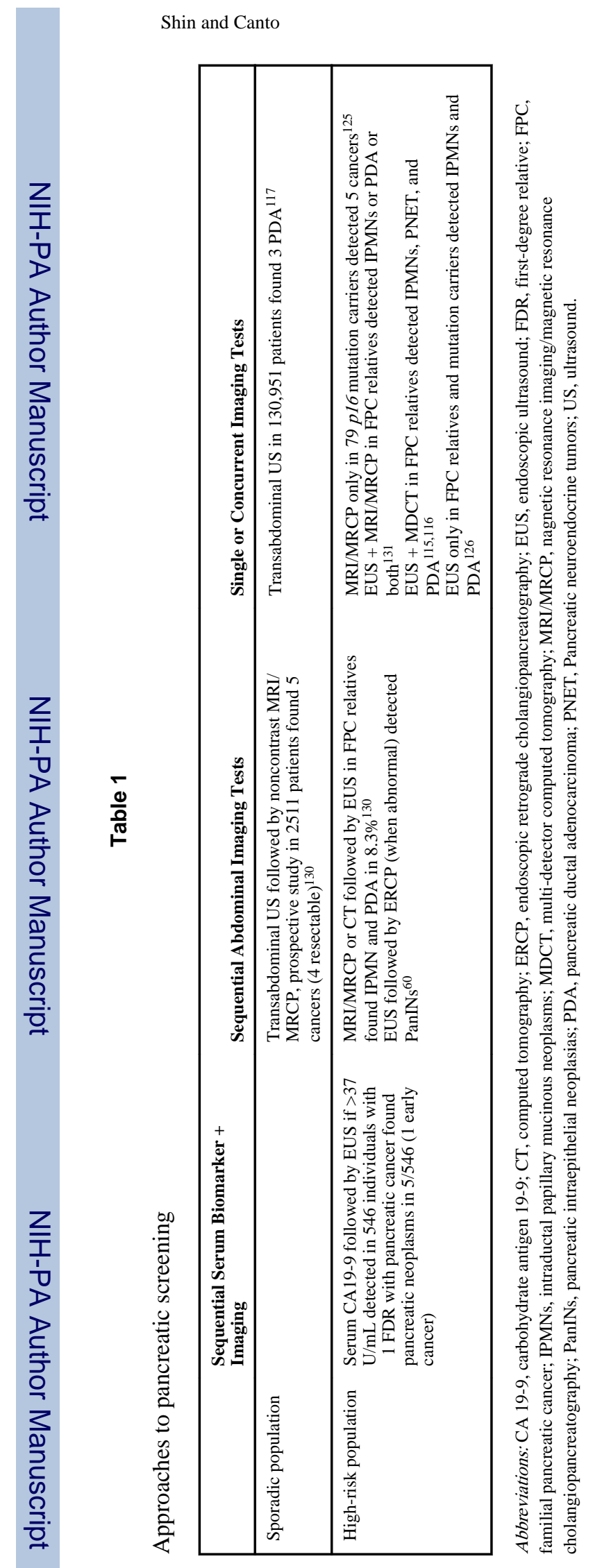

Page 14 